\title{
Analisis Industri Keramik di Indonesia
}

\author{
Andriati Fitria Wati, Elvina Yulistia Erwan, Nur \\ Azizah,PamelaJurdilla
}

Mahasiswa Kimia, FMIPA, Universitas Negeri Padang, Indonesia

*Email :andriatifitria99@gmail.com

\begin{abstract}
Abstrak.Industri keramik di Indonesia menurut Kementerian Perindustrian (KEMENPERIN) menilai bahwa akan mampu bersaing dipasar perdagangan Internasional, sebab proses produksi maupun pemasaran sudah melakukan penerapan teknologi yang canggih ke beberapa belahan dunia. Industri ini diprediksi akan terus maju dan mengkilap sebab, Indonesia memiliki keunggulan dan ketersediaan potensi sumber daya bahan baku seperti zircon, ball clay and feldspar dan kelimpahan gas sebagai bahan bakar produksi. Didalam artikel ini dapat digunakan beberapa metodemetode penulisan yaitu metede secara deskriptif kuantitatif dengan menggunakan sumber data sekunder dari literatur seperti buku dan jurnal yang relevan. Pemerintah dengan berbagai lembaga pihak terkait masih terus berupaya untuk menjadikan industri keramik dapat terus bersaing dipasar perdagangan internasional dengan melakukan kerja sama penelitian dan pelayanan teknis bersama BKK Bandung untuk mendukung adanya rasa kemandirian serta peningkatan yang dapat terus tumbuh dan melaju pesat untuk mewujudkan perekonomian yang bersifat secara nasional dan internasional yang unggul
\end{abstract}

Kata Kunci : Industri, Pemerintah, Keramik, Sumber daya, Perekonomian 


\section{Pendahuluan}

Keramik $^{[1-22]}$ sebagaimana diketahui berasal darisuatu bahasa yunani kuno, yaitu "Keramikos" dalam artian beberapa tanah liat yang sudah melalui tahapan yaitu pembakaran ${ }^{[23-30]}$. Dalam sebuah kamus dan ensiklopedi sekitar tahun 1950an ada berbagai sastrawan yang mengartikan suatu keramik sebagai seni serta teknologi yang dapat di jadikan beberapa bentuk yang sangat berguna seperti : porselen, gerabah serta yang lainnya yang dapat di peroleh dari tanah liat yang dibakar ${ }^{[31-36]}$. Seiring berkembangnya zaman, dapat diketahui bahwa produk utama keramik bukan hanya dari tanah liat saja, Bahan baku yang sangat utama yang di pakai dalam pembuatan serta umumnya dapat kita ketahui sendiri yaitu : kaolin, ball clay, felspard ${ }^{[37-40]}$ dan yang terakhir air.Sifat dan kualitas suatu keramik itu sendiri tergantung oleh bagian bentuk/struktur kristalnya maupun mineral yang telah terkandung didalamnya. Oleh sebab itu, keramik sangat ditentukan berdasarkan lingkungan geologi dimana bahan baku itu diperoleh ${ }^{[41]}$.

Menurut sejarah yang telah ada, Keramik merupakan kerajinan yang telah dijadikan produk tertua pada zaman kebudayaan manusia ${ }^{[42-44]}$, salah satu contoh Negara yang telah lama mengenal keranik yaitu orang Afrika Timur. Keramik merupakan bahan yang mencakup semua benda atau sesuatu yang dapat di buat biasanya dari tanah liat atau biasa disebut tanah lempung yang melalui beberapa tahapan-tahapan seperti menggunakan energi panas atau proses pembakaran sampai bentuknya mengeras. Suatu benda yang sering kali kita jumpai dikehidupan sehari-hari seperti keramik sesuai dengan fungsinya keramik dapat dikategorikan dalam berbagai jenis, antara lain : kebutuhan industri (refractory), kebutuhan rumah tangga (tile,bricks) dan lain sebagainya ${ }^{[45-48]}$.

Pada tahun 4500 sebelum masehi ini awal mulanya keramik dikenal di daerahShanxi yang terletak dikawasan negeri Cina .Keramik dapat produksi melalui bahan tradisional maupun bahan yang bermutu tinggi seperti contohnya untuk keramik yang berbahan dasar tradisional seperti kendi, pecah belah dan lain sebagainya, dan untuk bahan yang menggunakan kualitas tinggi yaitu bahan sifatnya tahan terhadap suhu tinggi yaitu flint dan feldfar bahan ini tahan terhadap suhu tinggi yang ketahanannya mencapai suhu $1200^{\circ} \mathrm{C}-2000^{\circ} \mathrm{C}^{[49-52]}$. Beberapa lembaga yang menjalankan penelitian di Indonesia terkait di bidang keramik tidak akan terlepas dari suatu pembuatan gagasan atau ide pemikiran untuk menciptakan suatu rancangan yang biasa di sebut dengan design ${ }^{[53]}$. Ada berbagai macam teknik yang bisa di buat menjadi bentuk prototype misalnya dapat di buat dengan berbagai cara yang berbeda-beda misalnya : cara pilin, cetak cor, sleb, dan dapat di lakukan dengan cara yang biasa yaitu dengan teknik putar ${ }^{[54-58]}$. Ada beberapa faktor yang mempengaruhi daya saing bagi pemasaran di dalam industri keramik, yaitu : penelitian dan pengembangan, pemasaran, produksi, sumber daya alam, serta keuangannya yang paling perlu untuk mengatur proses jalannya sebuah industry ${ }^{[59]}$. 


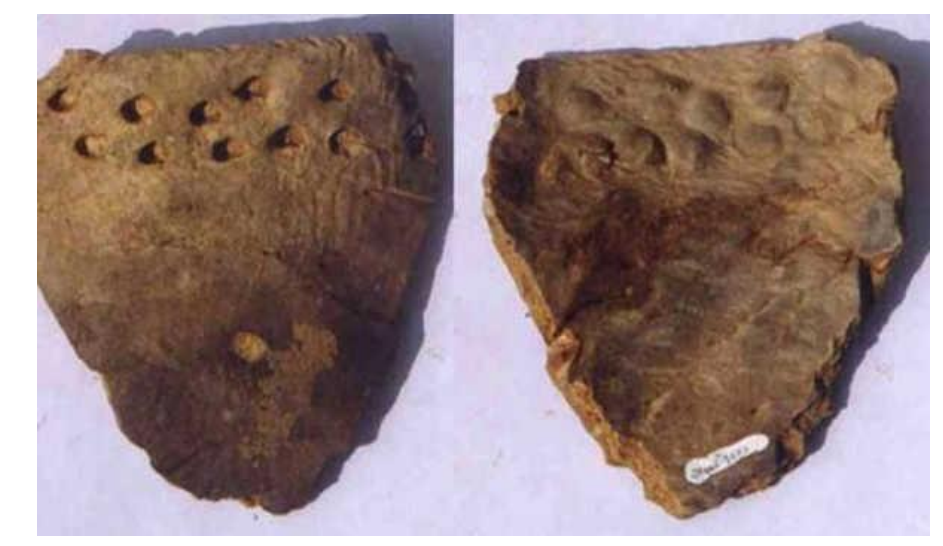

https://www.beritasatu.com/iptek/57077/keramik-tertua-ditemukan-di$\underline{\text { china }}$

Dapat kita ketahui pembuatan keramik tersebut berasal dari tanah liat, tanah liat itu sendiri banyak mengadung bahan kimia yang dapat di gunakan sebagai adsorben dan berfungsi untuk mengikat berbagai kation dalam proses pembuatan keramik $^{[60]}$. Adanya keramik di tengah-tengah masyarakat dapat menjadikannya suatu kerajinan yang sangat berguna untuk memenuhi berbagai pangsa pasar yang di butuhkan kalangan masyarakat dalam dan luar negeri, dengan berkembang pesatnya dekorasi dari keramik sendiri menjadi terlihat unik, sehingga dapat menarik perhatian pemerintahan untuk memberikan dana dan mampu mengembangkannya secara pesat ${ }^{[61]}$.

Dalam suatu usaha atau industri bahan baku menjadi bahan yang paling utama untuk pemenuhan produksinya, jika kurangnya bahan baku di dalam suatu industry maka akan berdampak sangat buruk hingga merugikan ${ }^{[62]}$. Salah satu aplikasi yang dapat di terapkan dalam industri keramik yaitu beberapa bahan yang mengandung silica sebagai isolator listrik dan panas ${ }^{[63-64]}$. Di era globalisasi pada saat ini, berbagai industri kecil misalnya keramik di tuntut agar dapat berkompetisi dan bersaing secara sehat untuk peningkatan angka prokdivitas dalam pemenuhan kelangsungan hidup ${ }^{[65]}$.

Ada suatu metode yang dapat memanfaatkan gas alam untuk mengetahui adanya pengaruh membran keramik yaitu $\mathrm{H}_{2} \mathrm{~S}$ terhadap daya adsorpsi yang terdapat di alam. Desain, salah satu kelebihan yang di miliki dari sumber daya manusia bersifat kontenporer yang menghasilkan suatu keramik yang memiliki estetika dan sesuai dengan trend terkini ${ }^{[6]}$. Daya kreativitas yang di dihasilkan oleh manusia itu sendiri yang membuat keramik lambat laun terjadinya perubahan, ada dua variable yang mempengaruhi yaitu pengaruh dari lingkungan serta pengaruh dari diri sendiri ${ }^{[67]}$.

Dalam keramik tersebut ada membran berbentuk geometri yaitu tubular dan flat. Kelebihan yang di milikinya cukup banyak yaitu : memiliki stabilitas termal yang baik dan adanya ketahanan terhadap senyawa kimia ${ }^{[68-69]}$.

Di Indonesia berbagai industri banyak menggunakan bahan stainless steel yang dapat di pakai dalam industri keramik untuk biomaterial dalam implant. Bahan baku yang akan di buat harus jelas secara karakteristik dan memenuhi standar syarat Departemen perindustrian Indonesia, baik secara fisika maupun 
kimia $^{[70]}$. Metode pembuatan keramik dapat di lakukan secara prototipe, sebagaimana dapat terlihat pada bagan di bawah ini :

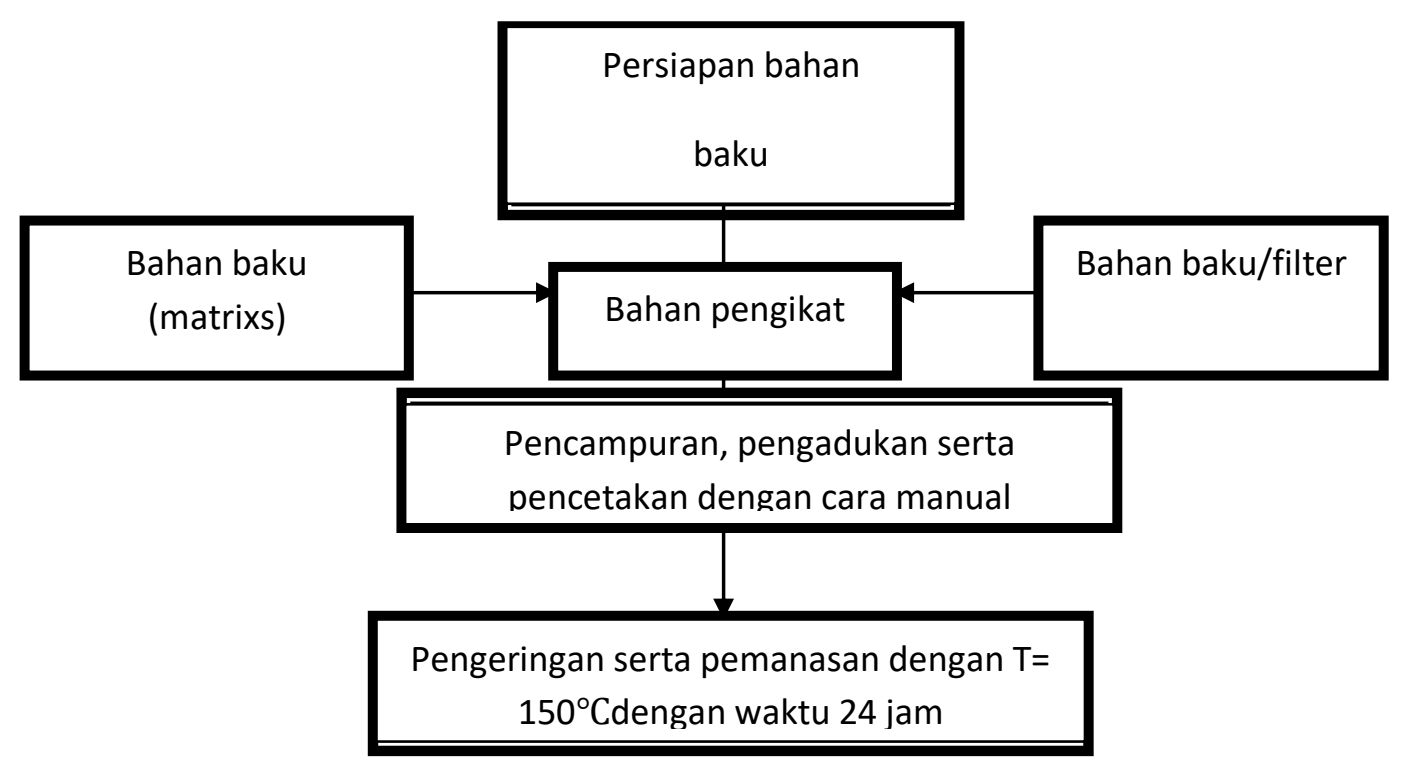

Diagram alir pembuatan produk pada keramik.

Kebanyakkan suatu usaha seperti adanya di dunia perindustrian, baik industri kecil maupun besar pasti memerlukan apa itu namanya biaya untuk kecukupan modal usahanya, modal tersebut dapat di peroleh dari modal tetap dan modal kerja. Salah satu material yang dapat di peroleh untuk pemenuhan suatu modal usaha keramik yaitu bahan baku yang berupa keramik tahan panas (refractories) berasal dari senyawa kimia yaitu Magnesium Oksida $(\mathrm{MgO})^{[71-73]}$.

Selanjutnya, keramik dapat di aplikasikan dalam bentuk Cordierite sebagai bahan material tahan terhadap suhu tinggi (refrakton), filter terhadap gas buangan serta berguna untuk pengkatalis filter beberapa gas beracun ${ }^{[74]}$. Ada beberapa tahapan atau langkah yang dapat dilakukan berkaitan dengan pemecahan mengenai masalah line balancing yang berkaitan dengan industri keramik yaitu : satu, melakukan survey pendahuan dengan tujuan ingin mengenal keadaan lingkungan industri yang mana akan berlanjut sebagai kerangka dasar dan tahapan yang ingin di buat ${ }^{[75]}$.

Dalam sebuah jurnal mengenai keramik, ada beberapa macam proses pembuatan yang telah di lakukan serta menggunakan bahan baku yang pastinya berbeda-beda, yang pertama yaitu proses slip casting yang mana pada tahapan ini menggunakan serbuk alumina sebagai bahan dasarnya yang harus di siapkan dalam bentuk suspense, yang kedua reaction bondingyang memanfaatkan campuran serbuk aluminium $(\mathrm{Al}){ }^{[76]}$. Ada beberapa konsep penerapan yang dapat di lakukan dalam aplikasi industri keramik, salah satunya yaitu : konsep six sigma, metode ini telah di terapkan dan terbukti dapat mengurangi cacat akan adanya variabilitas pada proses pengolahan keramik. Maka di lakukan sebuat terobosan terbaru untuk memperbaiki secara sistematis dengan adanya siklus DCAIM( Define, Control, Analyze, Improve dan Measur ${ }^{[77]}$. 
Sesuai dengan tuntunan zaman, beberapa industri baik di Indonesia maupun beberapa industri lainnya yang ada di luar negeri tidak terlalu memberikan perhatian lebih terhadap limbah pabriknya sendiri, malahan lebih fokus terhadap hasil yang mereka dapatkan dengan meraih keuntungan yang sebesar-besarnya, padahal banyak pollutan yang di hasilkan dari industri manapun, baik berupa limbah cair maupun gas ${ }^{[78-79]}$.

Agar tampak jelas di mata masyarakat industri keramik dapat memberikan hal-hal positif yang juga menguntungkan bagi masyarakat sekitar, dengan adanya pengolahan limbah yang begitu berbahaya terlebih dahulu atau di lakukannya filter, kemudian membuangnya ke tempat pembuangan limbah yang terakhir, begitu juga dengan gas buangan yang dapat mencemari udara sekitar yang berdampak sangat buruk bagi kesehatan ${ }^{[80]}$.

\section{Metodologi Penelitian}

Pada artikel ini, adapun metode penelitian yang dipilih ialah metode deskriptif $^{[101]}$ kualitatif.Dengan perolehan sumber data berupa sumber data sekunder yang didapat dari studi kepustakaan.Metode ini didasarkan dengan teknik pengumpulan data-data ${ }^{[92]}$ yang berkaitan dengan artikel dimana dapat diperoleh dari data penelitian sebelumnya maupun dari literature seperti buku, jurnal dan media online

\section{Pembahasan}

Keramik merupakan benda yang dekat dengan kehidupan kita seharihari.Industri keramik telah berkembang sejak 4500 tahun yang lalu sebelum masehi, yang merupakan usaha dari penduduk perkampungan neolitik di daerah Sanxi, China.Pada awalnya industri keramik hanya terfokus pada hasil pegolahan tembikar saja, yang mana tembikar tertua di dunia ditemukan di negara England yang diketahu dimulai sejak abad ke-16. Pada abad ke-17, industri tembikar mulai dikembangkan melalui Tofst Bersaudara dengan membuat hasil olahan berupa tembikar slip di Staffordshire. Perkembangan perubahan ${ }^{[110]}$ pengolahan tembikar menjadi industri keramik dimulai sejak abad ke-18, hingga saat sekarang ini industri pengolahan keramik juga terus berkembang.

Tidak hanya dibidang perindustrian, teknologi material bahan baku keramik juga mengalami perkembangan, yang saat ini diarahkan pada kespesifikasian fungsi dan kegunaannya dalam tiap-tiap kebutuhan. Baik industri yang berkaitan menangani kebutuhan-kebutuhan rumah tangga, perusahaan, refaktori, industri mekanik yang berkaitan denga mesin, cordierite, elektonika, serta teknologi ruang angkasa, keramik yang berpori dan kebutuhan-kebutuhan lainnya.Negara Indonesia merupakan negara dengan penghasil sumber daya ${ }^{[85]}$ material terbesar, dalam hal ini , material alam yang berlimpah berupa ketersediaan $\mathrm{Al}_{2} \mathrm{O}_{3}, \mathrm{SiO}_{2}$, $\mathrm{MgO}, \mathrm{CaO}, \mathrm{K}_{2} \mathrm{O}$ dan $\mathrm{Na}_{2} \mathrm{O}$ merupakan material yang dapat digunakan(81) sebagai bahan dasar utama dalam olahan produk industri ${ }^{[82]}$ yang menghasilkan keramik. Perkembangan beberapa industri keramik di Indonesia berbanding lurus seiring dengan meningkatnya kebutuhan masyarakat akan produk hasil olahan keramik yang dapat berupa ubin maupun hiasan.Seiring dengan peningkatan jumlah kebutuhan keramik di Indonesia, pemerintah mengharapkan hal ini dapat meningkatkan tingkat perekonomian negara. 


\subsection{Proses Pengolahan Industri Keramik}

\section{PROSES PEMBUATAN}

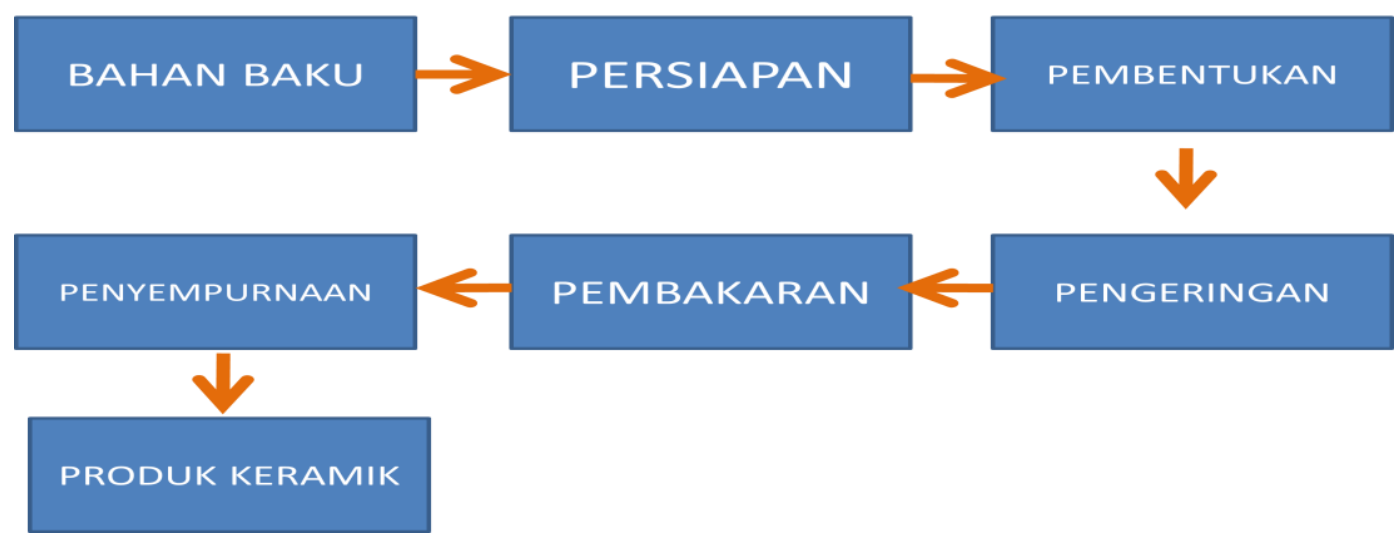

Industri keramik memiliki 3 bahan baku utama, diantaranya ialah :

a. Lempung ( Clay Mineral)

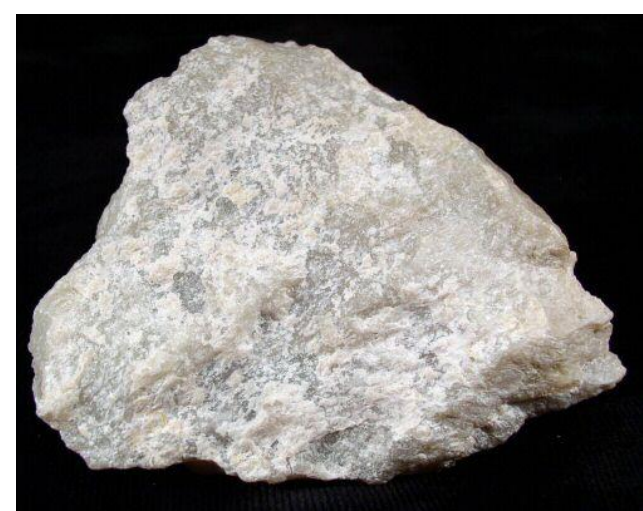

https://turkish.alibaba.com/g/soap-talc-stone.html

Lempung atau disebut juga Clay mineral merupakan hasil pelapukan dari suatu batuan beku yang berupa aluminium silika anhidrat yang tidak terlalu murni.Dimana batuan beku tersebut mengandung feldspar dalam bentuk ${ }^{[84]}$ suatu mineral yang penting.

Dalam hal ini, dihasilkan suatu reaksi yaitu :

$\mathrm{K}_{2} \mathrm{O} \cdot \mathrm{Al}_{2} \mathrm{SO}_{3} \cdot 6 \mathrm{SiO}_{2}+2 \mathrm{H}_{2} \mathrm{O}+\mathrm{CO}_{2} \rightarrow \mathrm{K}_{2} \mathrm{CO}_{3}+\mathrm{Al}_{2} \mathrm{O}_{3} \cdot 2 \mathrm{SiO}_{2} \cdot 2 \mathrm{H}_{2} \mathrm{O}+4 \mathrm{SiO}_{2}$

Ciri khas yang dimiliki daru material lempung ini ialah mudah dibentuk jika dalam keadaan basah dan cukup halus, dan akan kaku bila dalam keadaan kering serta akan berubah menjadi kaca (vitreous) apabila dibakar pada suhu tinggi. Ada beberapa spesies kategori yang dapat digolongkan kedalam mineral yang disebut mineral lempeng seperti caampuran montmorilonit [(Mg,Ca)O. $\left.\mathrm{Al}_{2} \mathrm{O}_{3} \cdot 5 \mathrm{SiO}_{2} \cdot \mathrm{nH}_{2} \mathrm{O}\right]$, serta didapat juga campuran kaolinit $\left(\mathrm{Al}_{2} \mathrm{O}_{3} .2 \mathrm{SiO}_{2} .2 \mathrm{H}_{2} \mathrm{O}\right)$ dan ilit $\left(\mathrm{K}_{2} \mathrm{O}, \mathrm{MgO}, \mathrm{Al}_{2} \mathrm{O}_{3}, \mathrm{SiO}_{2} .2 \mathrm{H}_{2} \mathrm{O}\right)$. 
b. Pasir

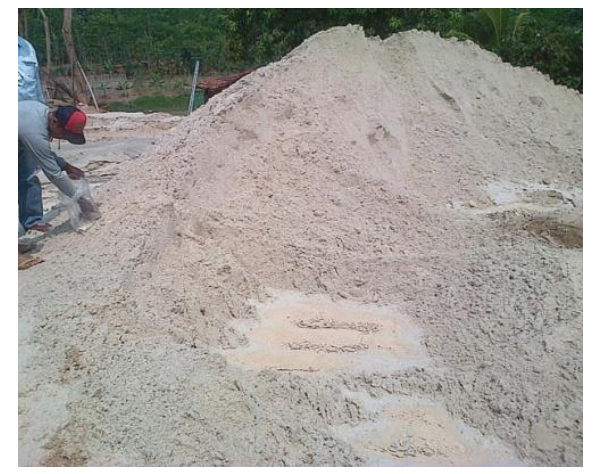

http://www.bbk.go.id/index.php/berita/view/41/POTENSI-PASIR-KUARSA

Pasir $^{[108]}$ merupakan bahan non plastic yang ditambahkan kedalam ${ }^{[94]}$ komposisi material olahan keramik yang memiliki fungsi untuk mengurangi penyusutan dan mengatur plastisitas serta mnaikkan temperature sintering.

c. Feldspar

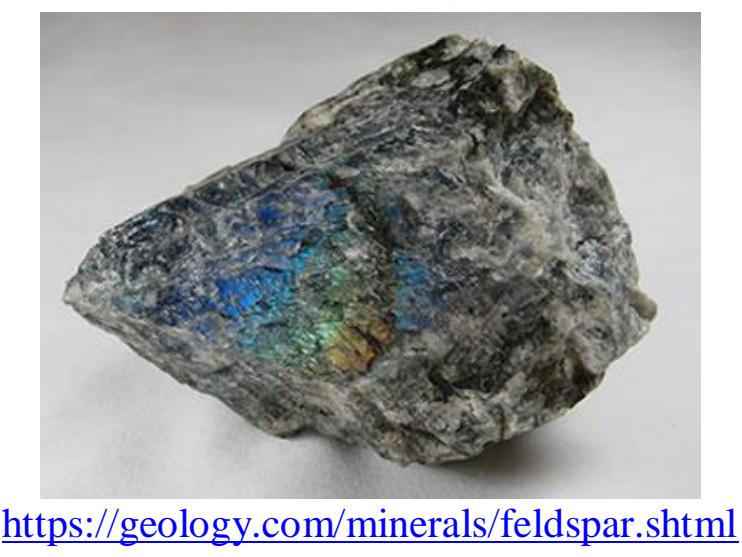

Feldspar merupakan bagian dari mineral-mineral yang diperoleh dari batuan-batuan karang, ditumbuk serta (dihaluskan).Feldspar memiliki sifat seperti tidak dapat larut didalam air, terkandung didalamnya silica, serta memiliki fluk dan kandungan alumina sebagaimana bahan-bahan itu dapat berfungsi ${ }^{[109]}$ sebagai memproduksi gelasir pada suhu yan tinggi.Feldspar akan melebur dan meleleh seperti leburan gelas apabila keramik dibakar. Leburan gelas ini akan meyebabkan partikel yang terkandung seperti beberapa $\operatorname{tanah}^{[85]}$ dan bagian lain yang dapat melekat atau menempel dari bagian satu dengan yang lainnnya. Apabila keramik dibekukan, akan memberikan power pada keramik sehingga badan keramik akan menjadi lebih kuat

Ada 3 jenis feldspar yang dapat diketahui, seperti :

d. $\mathrm{K}$ - feldspar (Al2O3.6SiO2.K2O)

e. $\mathrm{Ca}-$ feldspar(CaO.6SiO2.Al2O3)

f. $\mathrm{Na}-$ feldspar(Na2O.6SiO2.A12O3) 


\subsubsection{Persiapan Bahan}

Pada bagian tahap pemisahan, beberapa aktivitas yang dapat dilakukan seperti : Adanya proses pengolahan pada bagian pertama, lalu yang kedua pembersihan tanah lempung dari beberapa kotoran-kotoran yang menempel dan pembuangan bebatuan jika ada. Proses selanjutnya yaitu : pencucian dari pelapukan yang ada, perendaman sampel, pembasahan sampel, penggilingan sampel secara kasar maupun halus, pemberian berbagai zat kimia ${ }^{[17]}$, pencampuran serta polesan yang terakhir yaitu penguletan.

\subsubsection{Pembentukan}

Pembentukan sampel dapat ditentukan sesuai kadar air yang telah tertera sebelumnya, yaitu :

\begin{tabular}{ccc}
\hline No & Kondisi & Kadar \\
\hline 1. & Waktu Penuangan & $30-40 \%$ \\
2. & Waktu Sampel Lunak & $20-25 \%$ \\
3. & Waktu Sampel Keras & $15-20 \%$ \\
4. & Saat Setengan Kering & $5-10 \%$ \\
5. & Saat Pengeringan & $1-2 \%$ \\
6. & Saat Hidrostatis & $0-1 \%$ \\
\hline
\end{tabular}

Pembentukan sampel pada saat penuangan tidak dapat digunakan pada proses pembuatan pipa, genteng rumah maupun batu bata yang berasal dari tanah liat. Namun, proses ini digunakan oleh beberapa industri diantaranya ${ }^{[119]}$ dalam menghasilkan barang seperti : benda untuk hiasan atau pajangan, alat-alat yang berkaitan dengan rumah tangga, serta barang yang berbahan dasar porselin.Industri yang biasanya membuat barang yang bersifat plastis atau lunak biasanya itu adalah beberapa industri pengrajin. Yang hasilnya dapat diperoleh melalui proses pengeringan terlebih dahulu kemudian didapatkan hasil akhirnya.

Pembentukan dengan bahan keras yaitu bukan plastis ${ }^{[120]}$, biasanya dipakai oleh beberapa industri kalangan menengah maupun besar. Hasil yang didapatkan memiliki keuntungan yang fleksibilitas lebih besar dengan waktu yang tidak begitu lama dan dengan beberapa ukuran yang diinginkan.

Bentuk serta hasil yang didapat lebih maksimal karna adanya penyusutan yang lumayan sedikit yang dapat merubah bentuknya tidak secara signifikan, tetapi melalui beberapa tahapan. Sehingga, hasil akhir dari pengerjaan ini dapat langsung mudah dibentuk sesuai dengan apa yang kita inginkan, misalnya :dalam pembentukan tahap akhir pembuatan genteng, atau tahap extarden dari pipa. Tahapan yang biasa digunakan oleh beberapa industri yaitu tahap kering maupun setengah kering, misalnya dalam pembentukan ubin dalam berbagai industri lainnya, akan tetapi, di Indonesia belum ada yang melakukan proses secara hidrostatis.

\subsubsection{Pengeringan}

Biasanya, keramik yang apabila telah selesai dibentuk akan menghasilkan kandungan air yang berkisar antara 7-30\%. Namun, hal ini juga tergantung pada proses pembentukannya. Keramik yang masih dalam keadaan mentah, biasanya berwujud basah sehingga untuk perlu dilakukan proses pengeringan ${ }^{[99]}$ untuk mengurangi kandungan air yang terdapat pada keramik tersebut. tujuan dari 
proses pengeringan ini ialah untuk menguapkan air yang masih terkandung komposisi material keramik. Hal ini dilakukan agar apabila keramik dibakar nantinya tidak terjadi perubahan pada sifat dan bentuk keramik yang dihasilkan, juga untuk menghindari kerusakan.

Adapun hal yang terjadi pada proses pengeringan ini ialah terjadinya penyusutan kandungan air dimana air yang berada pada materil mentah komposisi keramik akan menguap. Adapun tujuan dari proses pengeringan ini ialah :

1. Penghilangan kandungan air dalam sampel

2. Membantu proses barang setengah jadi kuat atau kaku

Pada tahapan pengeringan untuk produk yang masih mentah, dapat dilakukan dengan 2 tahapan yang berbeda.Yaitu dengan tahap alami maupun tahap buatan. Tahap pengeringan dengan cara alami dilakukan dengan memanfaatkan paparan sinar matahari untuk mengeringkan hasil olahan bahan mentah keramik tersebut. Sedangkan pada metode pengeringan buatan dilakukan dengan menggunakan tungku pemanas yang mana memanfaatkan ${ }^{[100]}$ radiasi dari panas yang dihasilkan oleh tungku untuk mengeringkan hasil bahan mentah olahan keramik.

\subsubsection{Pembakaran}

Proses pembakaran ${ }^{[91]}$ bertujuan untuk mendapatkan suatu hasil atau produk yang sesuai dengan sifat-sifat yang sudah terpenuhi, seperti :

1. Kekuatan secara mekanis yang cukup tinggi

2. Sesuai dengan sifat fisikanya ${ }^{(118)}$

3. Sesuai dengan sifat kimianya

Adapun perubahan secara kimia ${ }^{[103]}$ atau konversi dapat terjadi pada proses pembakaran dari hasil ${ }^{[102]}$ olahan keramik, seperti :

1. Dehidrasi pada $\mathrm{H}_{2} \mathrm{O}$ yang sudah terikat $150-160$

$\mathrm{Al}_{2} \mathrm{SO}_{3} \cdot 2 \mathrm{SiO}_{2} \cdot 2 \mathrm{H}_{2} \mathrm{O} \rightarrow \mathrm{Al}_{2} \mathrm{O}_{3}+2 \mathrm{SiO}_{2}+2 \mathrm{H}_{2} \mathrm{O}$

2. Kalsinasi pada $\mathrm{CaCO}_{3}$ saat 600-900

3. Oksidasi besi serta bahan organik saat $300-900$

4. Pembentukan silikat diatas $\mathrm{T}=900$

Tahapan pada proses di bakar :

1. penguapan air saat mekanis atau disebut water smoking

2. pra pemanasan (preheating)

3. sampel dibakar pada saat suhu yang tinggi

4. sampel didinginkan

5. dibakarnya sampel pada 2 kilu tungku pada proses dibakar secara continu sertasecara berurutan

Tabel pada pengubahan sampel dimensi sesudah pembakaran berlangsungdengan temperature yang berbeda, yaitu:

\begin{tabular}{ccccc}
\hline $\begin{array}{c}\text { T Sinter } \\
\left({ }^{\circ} \mathrm{C}\right)\end{array}$ & $\begin{array}{c}\Delta d \\
(\mathrm{~mm})\end{array}$ & $\Delta h(\mathrm{~mm})$ & $\mathrm{d}(\%)$ & $\mathrm{h}(\%)$ \\
\hline 1000 & 0 & 0,1 & 0 & 2,4
\end{tabular}




\begin{tabular}{ccccc}
1200 & 0 & 0,07 & 0 & 1,7 \\
1300 & 0 & 0 & 0 & 0 \\
1400 & 0 & 0 & 0 & 0 \\
\hline
\end{tabular}

\subsubsection{Hasil Olahan Produk Keramik}

Produk hasil olahan keramik telah banyak digunakan ${ }^{[97]}$ sebagian besar orang.Baik itu sebagai hiasan, produk kebutuhan rumah tangga seperti piring, mangkok, cangki dan semacamnya.Hasil olahan keramik juga dimanfaatkan orang-orang sebagai bahan dasar dari bangunan yang membutuhkan dasar keramik seperti genteng dari keramik dll. Atau, hasil olahan keramik juga dapat dimanfaatkan untuk keperluan khusus seperti pembuatan keramik isolator yang penggunaannya dikhususkan untuk kebutuhan dan industri perlistikan saja.

Semakin berkembangnya dunia teknologi, industri keramik juga ikut berkembang.Bahkan saat ini, hasil olahan keramik telah digunakan pada berbagai bidang ilmu seperti keperluan ilmu science dalam pembuatan bio cramics.Yang mana bio cramics ini digunakan untuk menggantikan organ tubuh manusia yang telah mengalami kerusakan seperti pada bagian tulang dan gigi

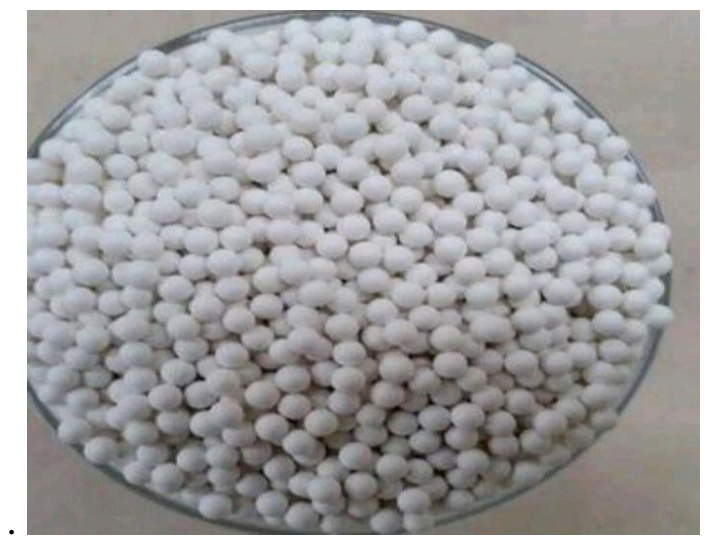

https://www.olx.co.id/iklan/bio-ceramic-500-gram-IDxwLB5.html

Selain itu,hasil olahan produk keramik juga banyak digunakan pada bidang elektonik. Pada biang antariksa dan kedirgantaraan pun memanfaatkan produk keramik dalam pembuatan beberapa bagian luar maupun bagian dalam pesawat yang kini telah digunakan dan berbagai pesawat lainnya baik jet maupun pesawat luar angkasa.

Hasil olahan dari keramik juga dapat digunakan dalam berbagai industri ${ }^{[104]}$ lainnya misalnya dalam teknologi nuklir. Karena sifat keramik adalah tidak rentan terhadap suhu tinggi, kuat, dan merupakan isolator ( benda yang tidak dapay menghantarkan panas). Keramik juga dianggap sebagai bahan yang mampu menangani radiasi dari nuklir itu sendiri, sehingga keramik dimanfaatkan untuk reactordalamteknologi nuklir karna dapat mencegah penyebaran pancaran sinar radiasi agar tidak terlalu bahaya bagi makhluk hidup disekitarnya dan juga manusia.

Berikut ini adalah beberapa contoh dari penggunaan keramik:

1. Alat-alat ${ }^{[95]}$ ynag terbuat dari alumina serta silikon nitrida dimanfaatkan sebagai pembentukan dan pemotongan logam serta penghancur logam. 
2. Untuk tipe keramik zirconias, silikon nitrida dan karbida dimanfaatkan ${ }^{\text {[93] }}$ sebagai saluran rotorturbocharger pada saat temperatur tinggi.

3. Keramik dapat dimanfaatkan sebagai insulator yaitu aluminum oksida $\left(\mathrm{AlO}_{3}\right)$. Jika bersifat semikonduktor ${ }^{[114]}$ dapat menggunakan barium titanate $\left(\mathrm{BaTiO}_{3}\right)$. Terkhusus keramik yang bersifat superkonduktor digunakan tembaga oksida.

4. Sebagai pelapis pelindung dari panas ${ }^{[86]}$ pada pesawat menggunakan keramik dari campuran semen dan logam.

5. Pemanfaatan biomedical yang berjenis alumina porous dapat dimanfaatkan untuk implant pada bagian tubuh manusia serta yang berkaitan pada jaringan tubuh.

6. Dalam pembangkit tenaga nuklir dapat memanfaatkan butiran uranium yang terbentuk dari gas $\mathrm{UF}_{6}$.

7. Industri yang menggunakan metode feldspar ataupun juga tanah liat ini biasanya juga digunakan bagi indusri yang khusus membuat bahan bangunan

8. Dapat digunakan untuk pencegahan besi yang berkorosi. Jenis yang biasa digunakan yaitu enamel, barang-barang yang menggunakan pelapisan ini yaitu :mesin pengering, kompor, kulkas dll.

\subsubsection{Bahaya}

Tingakat kebahayaan keramik tergantung pada warna keramik

tersebut.semakin putih warna keramik, maka semakin tinggi kadar dan bahaya radioaktifnya akan mempengaruhi penghuni suatu rumah. Oleh karena itu ${ }^{[89]}$. Semakin putih keramik, itu mennadakan bahwa semakin tinggi kandungan Zirconium (Zr) pada keramik tersebut yang dapat memberikan efek buruk menyebabkan kanker kulit dalam jangaka waktu panjang.

\subsection{Perkembangan Industri Keramik di Indonesia}

Dapat kita ketahui, Pada 30 tahun terakhir ini beberapa industri yang berada di Indonesia yaitu industri keramik telah menjadi industri yang bersifat unggul ${ }^{[96]}$, baik dilihat secara nasional maupun internasional, prospek kerja dari industri keramik sendiri memilki peluang yang sangat besar sehingga jangka waktu yang didapatpun akan cukup panjang. Seiring berjalannya waktu dan berkembang pesatnya teknologi, pertumbuhan pasarpun ikut mengalami peningkatan yang signifikan, terutama dalam hal cakupan yang berbahan dasar bangunan seperti: tile atau ubin. Kualitas yang dimiliki industri dari dalam negeripun tidak kalah saing dari industri ternama dari Negara-negara di dunia lainnya. Sumber ini terbukti bahawa, Indonesia telah menduduki peringkat keenam dari beberapa Negara di dunia lainnya yang menjadi produsen terbaik yang telah dikatakan oleh Wakil Kementerian $^{[115]}$ Perindustrian Dunia yaitu Alex S.W Retraubun.

Produksi dari keramik nasional di setiap tahunnya dapat mengalami peningkatan baik secara signifikan maupun secara perlahan-lahan. Karena adanya pelayanan berupa kontribusi yang begitu layak dan juga baik dapat mendukung pertumbuhan perekonomian nasional bagi industri keramik itu sendiri, Oleh karena itu, industri-industri kini mulai bersaing ${ }^{[112]}$ dalam peningkatannya kualitas design untuk menarik perhatian yang berguna merebut pangsa pasar baik dari dalam negeri maupun di luar negeri. Adapun keunggulan yang dimiliki industri 
keramik nasional yaitu karna banyaknya tersedia bahan baku ${ }^{[105]}$ dari alam yang membantu mencukupi dalam proses pembuatan keramik, seperti yang diketahui bahan bakunya adalah : zircon, ball clay maupun beberapa energi gas dari alam sebagai bahan bakar pada proses produksi. Itu adalah salah satu keuntungan besar dalam upaya peningkatan daya ${ }^{[117]}$ saing dalam produksi keramik. Produksi keramik itu sendiri dalam setiap tahunnya mengalami peningkatan karna adanya peningkatan kontribusi yang tinggi serta mendukung tumbuh dan berkembangnya perekonomian yang ada di Indonesia.

Produk-produk yang telah dihasilkan dari industri keramik yang bersifat nasional masih dapat dikembangkan, karna konsumsi keramik masih menunjukkan angka $1 \mathrm{~m}^{2}$ dari data yang didapat dengan perbandingan Negara ASEAN yang sudah mencapai angka $2 \mathrm{~m}^{2}$. Dengan jumlah penduduk 250 juta jiwa serta banyaknya dukungan dari instansi pemerintahan, karena itu industri keramik dapat meningkatan prosperk kerja dan peluang pasar.

Sebelum didirikannya industri keramik tersebut, Kementerian Perindustriaan telah memberikan langkah strategis untuk upaya pengembangan industri keramik, berupa : yang pertama itu adalah upaya peningkatan pemakaian produk lokal atau disebut dengan P3DN serta badan yang bertugas mengawas pelaksanaan standar dalam negeri (SNI) yang beredar di pasar dari dalam negeri. Dengan tumbuh berkembangnya produksi keramik setiap tahunnya dengan adanya konstribusi baik yang di lakukan sebagai penunjang pertumbuhan ekonomi ${ }^{[83]}$ nasional yang di dapat dari perolehan devisa Negara, beberapa penyerapan tenaga kerja dan juga dalam penyediaan kebutuhan secara domestik.

Dapat disampaikan, sekitar tahun 2014 industri keramik yang berada di Indonesia dapat memperoleh kapasitas dari memproduksi keramik sebesar 1,8 juta $\mathrm{m}^{2} /$ hari terkhusus untuk kapasitar dan 1,6 juta $\mathrm{m}^{2} /$ hari untuk produksi keramiknya saja. Hasil produksi keramik itu sendiri didapatkan totalnya sebesar $87 \%$ yang telah diserap oleh pasar okas dan 13\% didapat dari ekspor.Pada tahun 2015, Nilai penjualan keramik dapat mencapai angka $\mathrm{Rp} 30$ triliun dan telah di proyeksikan dapat mencapai angka Rp 36 triliun. Pada saat ini produsen keramik lantai dan dinding berjumlah 35 perusahaan dengan jumlah pabrik keseluruhan sebesar 95 unit secara total total keseluruhan dapat mempekerjakan beberapa tenaga kerja sebanyak 200.000 orang. Kisaran tahun 2011, industri keramik yang memproduksi tile telah menghasilkan total secara keseluruhan tilenya 10,1 miliar meter persegi. Di dunia, industri yang memproduksi tile sebanyak 317 meter persegi atau jika di persenkan menjadi 3\%. Yang menduduki tingkat teratas dalam produksi tile yaitu Negara china yang mampu menghasilakan ${ }^{[121]}$ sebesar 4,8 miliar persegi atau dapat menguasai $45,7 \%$ dari total tile yang di peroleh secara mendunia.Mantan Ketua asosiasi Aneka Keramik Indonesia atau yang disebut ASAKI, yaitu Achmad Widjaya telah mengungkapkan, "total nilai penjualan atau omzet yang didapatkan dari industri keramik itu sendiri di Indonesia sepanjang kuartal I hingga pada tahun 2012 telah mencapai angka Rp 4,6 triliun. Angka tersebut berbanding sama dengan angka yang telah dicapai pada tahun lalu, dimana omzet yang telah didapatkan tidak sampai mencapai angka Rp 5 triliun, hanya berkisar $\mathrm{Rp} \mathrm{4,6}$ triliun saja. Padahal, target awal yang telah di buat untuk industri keramik ini bisa saja mencapai angka Rp 6 triliun.Selanjutmya, Achmad Widjaya telah menjelaskan alasan kenapa beberapa targer tersebut tidak tercapai sepenuhnya yaitu karena minimnya ketersediaan pasokan gas dan 
pemerintah.Dapat diketahui gas merupakan sumber energy yang paling utama untuk pemenuhan produksi industri keramik untuk menghasilkan produksi yang berkualitas. Kebutuhan gas untuk industri keramik itu sendiri dapat mencapai angka $30 \%$ dari seluruh total biaya produksinya. Dari total keseluruhannya itu, kebutuhan gas untuk industri keramik dapat mencapai angka 140 juta standar kaki kubik/hari (milimile standard cubic feet perday/mmscfd). Pada saat ini pemerintahan hanya dapat memenuhi kebutuhan gas sebesar 80 mmscfd. Karena, pasokan gas masi jauh dari angka kebutuhan tersebut akan berdampak bagi industri keramik yaitu adanya utilisasi keramik yang belum optimal.

Pada awalnya Achmad Widjaya telah memprediksi, pada tahun 2012 omzet yang ada pada industri keramik di Indonesia telah mencapai kisaran ${ }^{[87]}$ angka Rp 20 triliun. Angka tersebut dapat naik menjadi 17,6\% dibandingkan dengan pada tahun sebelumnya yaitu tahun 2011 yaitu mencapai angka sebesar Rp 17 triliun. Pada tahun 2011 tersebut utilisasi kapasitas telah terpasang pada beberapa industri keramik yang mencapai angka 243 juta meter persegi atau jika dipersentasekan ${ }^{\text {[98] }}$ menjadi $85 \%$ dari seluruh total kapasitas keramiknya. Sementara itu, dengan adanya penambahan kecil beberapa ekspansi wilayah, maka kapasitasnyapun bertambah hingga mencapai angka 250 juta meter persegi pada tahun ini. Untuk mencapai target yang telah ditentukan sebelumnya, selain peningkatan kapasitas yang telah dilakukan, perbaikan pada beberapa infrastruktur dan penambahan pasokan gas juga harus secara maksimal terpenuhi. Tanpa adanya itu, targer-target yang telah dibuat dapat dipastikan tidak akan tercapai seutuhnya. Selain itu, Achmad Widjaya telah menambahkan, beberapa kondisi pasar ekspor keramik sekarang ini semakin lama semakin memprihatinkan karena telah mengalami penurunan yang sangat signifikan dalam tiga tahun terakhir.

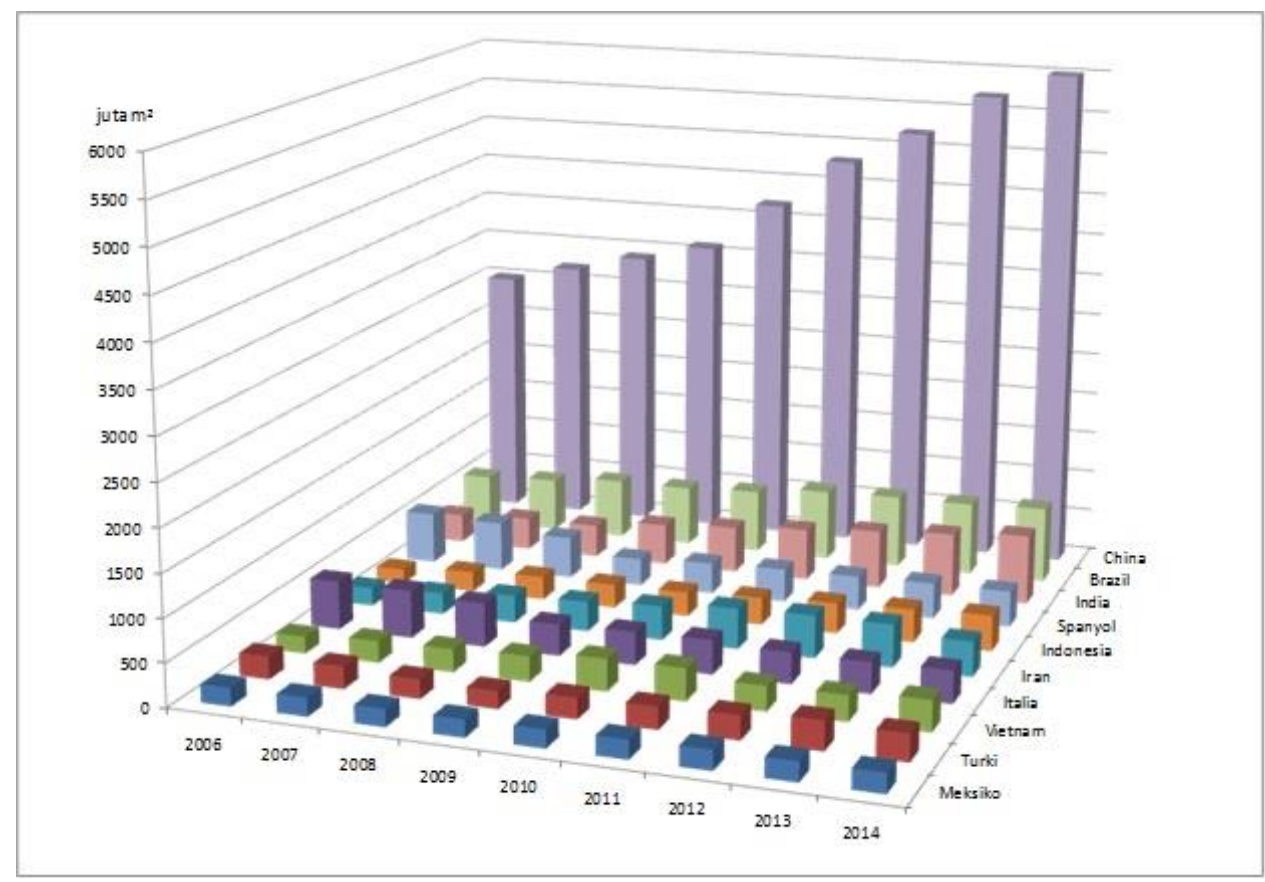

http://www.bbk.go.id/index.php/berita/view/184/Ubin-Keramik-IndonesiaTahun-2006-2014 
Balai Besar Keramik yaitu (BBK) Bandung memiliki peranan yang ${ }^{[106]}$ sangat strategis dalam menjawab berbagai peluang serta tantangan yang berguna untuk perkembangan usaha industri keramik nasional yang dapat melalui kegiatan teknologi, dapat di peroleh juga dari pelayanan jasa teknis berupa adanya bimbingan teknis yang intensif dari serta terakhir adanya penjaminan mutu terhadap produk keramik tersebut. Selain itu, tugas dari BBK juga senantiasa melakukan berbagai bentuk inovasi, yang terpenting terhadap bahan baku pada pembuatan keramik, selama proses pembuatannya, teknologi serta design dari produk yang telah melahirkan ide-ide baru yang kreatif yang sangat berguna untuk meningkatkan kualitas dan juga mutu dalam produk keramik. Kerjasama yang dilakukan beberapa penelitian ${ }^{[11]}$ serta pelayanan teknis yang telah di jalankan oleh BBK dengan industri keramik nasional yang banyak membuahkan hasil yang telah banyak diaplikasikan langsung oleh industri keramik, dimulai dari pengendalian bahan baku dan mutu keramik, produksi yang mencakup (kalibrasi, standarisasi serta sertifikasi), adanya peningkatan efisiensi ${ }^{[107]}$ terhadap proses produksi, terkendalinya lingkungan secara (internal dan juga eksternal), serta pengembangan dan pembangunan kapasitas industri (produk dalam sumber daya manusia).

Dengan berkembangnya zaman, tantangan yang dihadapi perekonomian akan semakin besar. Oleh karena itu, kemandirian harus lebih di tingkatkan sehingga daya saing industripun ikut meningkat pesat dan industri tersebut harus dapat tumbuh serta dapat diandalkan untuk mewujudkan perekonomian yang kini masi belum banyak tercapai. Visi dan misi dari industri itu sendiri dapat menyokong dalam bentuk merealisasikan segala bentuk program dan dukungan yang membuatnya berjalan secara terarah melalui beberapa program sesuai dengan kebutuhan, kualitas tinggi dari industri itu sendiri yang mampu mendayagunakan potensi industri yang menjadi titik tumpu keunggulan dalam negeri. Oleh sebab itu, diperlukan peningkatan terhadap prospek kerja dalam penelitian yang efektif, bukan hanya sekedar pemenuhan angka kredit namun juga dapat memberikan solusi bagi persoalan yang kini kerap terjadi di banyak industri, peningkatan kerjasama dan komunikasi yang sinergi di beberapa institusi, serta keterbukaan industri yang satu dengan yang lain bekerja sama dengan institusi penelitian. Maka, akan terjalinnya hubungan antara pihak kemitraan yang samasama saling menguntungkan bagi kedua belah pihak yaitu antara balai besar keramik dan masyarakat industri keramik dan juga beberapa lembaga litbang lainnya, diharapkan dapat dengan adanya ini dapat menjadi kekuatan yang mampu memecahkan serta menjawab semua permasalahan ${ }^{[88]}$ dan tantangan yang ada, terutama dalam mendukung pengembangan beberapa industri keramik nasional.

\section{Kesimpulan}

Dapat diketahui bahwasannya keramik dapat terbentuk dari bahan yaitu tanah liat yang biasa banyak ditemukan di alam, melalui beberapa tahapan ataupun proses yaitu kwarsa, serbuk kaca dan juga feldsfar. Sehingga, struktur dari keramik itu sendiri dapat ditentukan dari struktur penyusun Kristal, komposisi yang terkandung di dalamnya dan juga mineral bawaannya. Alat-alat rumah tangga yang biasa dipakai semuanya berasal dari bahan keramik misalnya $^{[113]}$ : teko, cangkir dll. Bukan hanya di gunakan dalam pemenuhan 
kebutuhan rumah tangga keramik juga di butuhkan untuk bahan bangunan seperti : batu-bata, tile, serta pipa keramik yang berfungsi sebagai pembuangan.

Industri-industri yang ada di Indonesia seperti industri keramik telah mampu bersaing baik secara lokal maupun internasional. Teknik pengolahan keramik ini pun telah menggunakan peralatan dan teknologi canggih ${ }^{[90]}$. Beberapa industri keramik di Indonesia yang bertaraf nasional pasti memiliki keunggulan dibandingkan dengan produsen yang dimiliki oleh beberapa Negara lain antara lain karna ketersediaannya deposit dalam bahan baku pada olahan keramik yang terbilang cukup besar di seluruh wilayah Indonesia contohnya: zircon, ball clay serta bahan bakar gas untuk membantu proses produksi.

\section{REFERENSI}

[1] Hidayat,C.N.( 2015 ). "Pengaruh Lingkungan Kerja dan Motivasi Kerja Terhadap Kinerja Karyawan Kantor Pt. Keramik Diaamond Industry. Agora. 3(2)

[2] Ilcham, A. 2013 . "Pengaruh Oil Sludge Pertamina Surabaya Terhadap Kekuatan Tekan Keramik Tradisional". Eksergi, 11(1), 11-15.

[3] Susanti, C. E. (2003). “Analisis Presepsi Konsumen Terhadap Kualitas Produk Keramik Merk Milan ddi Surabaya" Management and Accounting. $3(2)$.

[4] Hutasoit,J.P., et al. ( 2017 ) . "Analisis Produktivitas tenaga Kerja Konstruksi Pada Pekerjaan Pasangan lantai Keramik dan Plesteran Dinding Menggunakan Metode Work Sampling. Sipil Statik. 5(4)

[5] Ari,W.C.( 2010 ). "Pengaruh Penambahan Kaolin Terhadap Kualitas Genteng Keramik Ditinjau dari Penyerapan Air daan Kuat Lentur . (Doctoral Dissertation).

[6] Sundari,K.N. 2011 . "Sikap Kerja yang Menimbulkan Keluhan Muskuloskeleta an Meningkatkan Bebean kerja Pada Tukang Bentuk Keramik" .Teknik Industri. 10(1)

[7] Hadiati, S. 2009 . "Perilaku Wirausaha Industri Keramik Berskala kecil Untuk Meningkatkan Daya Saing Produk di Malang”. Manajemen dan Kewirausahaan. 10(2)

[8] Priadi,C.R., Anita,A., et al. ( 2014 ) . "Adsorpsi Logam Seng (Zn) dan Timbal $(\mathrm{Pb})$ pada Limbah Cair Industri Keramik oleh Tanah Liat" Reaktor. Vol.15(1)

[9] Purwanto, A. (2014). "Modal Budaya dan Modal Sosial Dalam Industri Seni Kerajinan Keramik". Sosiologi.

[10] Susanti,L., Machfudd,M an Hasbullah. 2015 . "Pengendalian Persediaan Bahan Baku Base Material Pada Industri Keramik di PPT. XYZ”. Aplikasi Bisnis dan Manajemen. 1(2)

[11] Sembiring,S., MAnurung,P dan Karo-karo,P. 2009 . "Pengaruh Suhu Tinggi Terhadap Karakteristik Keramik Cordierite Berbasis Silika Sekam Padi". Fisika dan Aplikasinya. 5(1)

[12] Purnomo,H., Manuaba,A dan Adiputra,N. 2007 . "Sistem Kerja Dengan Pendekatan Ergonomi Total Mengurangi Keluhan Musku;oskeletal, Kelelahan dan Beban Kerja Serta Meningkatkan Produktivitas Pekerja Industri Gerabah di Kasongan Bantul”. 
[13] Arsip,F dan Okta,T. 2013 . "Asorbsi $\mathrm{H}_{2} \mathrm{~S}$ Padaa Gas Alam Menggunakan Membran Keramik Dengan Metodee Titrasi Iodometri”. Teknik Kimia. 19(4).

[14] Permadi,B., Nurmalina,R dan Kirbrandoko,K. 2016. “Analisi Pengembangan Model Bisnis Kanvas CV Kanur Keramik Banding”. Aplikasi Manajemen. Vol.14(1).

[15] Hadiprojo, A. C. 2014 . "Niche Market Srategy pada Indusrri keramik Kasongan, Yogyakarta”

[16] Garinas,W. 2012 . "Karakteristik Bahan Baku Kaolin Untuk Bahan Pembuatan Badan Isolator Listrik Keraamik Porselen Fuse Cut Out ( FCO )". Sains dan Teknologi Indonesia. Vol.11(2)

[17] Suseno,T. et al. 2015 . "Analisi Prospek Pemanfaatan Zirkon alam Industri Keramik, Frit, Bta Tahan Api dan Pengecoran Logam”. Teknologi Mineral dan Batubara. 11(2)

[18] Novianti,W.S dan Wijaya,I. 2017 . “ Analisi Kinerja Keuangan Pada Industri Keramik, Porselen dan Kaca yang Terdaftar di BEI Periode 20112014" Mahasiswa Bina Islami. Vol.1(2)

[19] Savitri, E. S., \& Yulianti, E. (2012). "Pemanfaatan Biji Kelor ( Moringa oleifera Lamk ) Sebagai Bioflokulan Logam Berat $\mathrm{Cr}, \mathrm{Hg}$ dan $\mathrm{Pb}$ Pada Limbah Cair Industri Keramik Dinoyo Malang El-Qudwah.

[20] Pantow,M.S.R., Murni,S dan Trang,I. 2015 . “Analisa Pertumbuhan Penjualan, Ukuran Perusahaan, Return On Asset dan Struktur Modal Terhadap Nilai Perusahaan yang Tercatat di Indeks LQ45. EMBA : Riset Ekonomi, Manajemen, Bisnis dan Akuntansi. Vol.3(1)

[21] Nasir,S. 2013 . "Aplikasi Filter Keramik Berbasis tanah Liat Alam dari Zeolit Pada Pengolahan Air Limbah Hasil Proses Laundry” Environment. Vol.13(1)

[22] Respati,S.M.B . 2010 . "Bahan Biomaterial Stainless Steel dan Keramik". Majalah Ilmiah.Vol.6(1)

[23] Winarno, T . 2016. "Perbandingan Karakteristik Lempung Kasongan dan Godean Sebahan Bahan Baku Industri Gerabah Kasongan”. Teknik .Vol.73(1)

[24] Arifin,D.N dan Hartanto, P . 2010 . "Pengembangan Zeokeramik Berbahan baku Limbah Padaat Industri Sebagai Bahan Banginan Ramah Lingkungan". Geoteknologi LIPI.

[25] Ismanto,A.L . 2013 . "Pengaruh Manajemen Modal Kerja Terhadap Profitabilitas. Doctoral Dissertation. Universitas Negeri Semarang

[26] Syukur, M. ( 2008 ). “ Potensi Ubur-Ubur Sebagai Sumber Material Baku Keramik Tahan Api"

[27] Normal, I. N., \& Nurani, N. N. (2017). "Penerapan Upah Minimum Regional Tahun 2016 Dalam Menentukan Tarif Jasa Teknologi Desain Dulang Keramik". STMI Handayani Denpasar (Vol. 14, No. 2, pp. 15-28).

[28] Sinaga,T.2014. "Pengukuran Keseimbangan Lintasan Produksi Keramik Dengan Metode Helgeson dan Birnie di PT. XYZ". Teknologi Technoscientia. Vol.7(1)

[29] Anggono, J., Wibisono, G., Tjitro, S., \& Wiyono, D. E. 2008 . "Penyusutan dan Densifikasi Keramim Alumina : Perbandingan Antara Hasil Proses Slip Casting dengan Reaction Bounding". 
[30] Garside, A. K. "Peningkatan Kualitas Produk Keramik dengan Pendekatan Six Sigma Pada Industri Keramik", 6(1), 18-28.

[31] Sebayang, P., Muljadi, M., \& Ginting, M. . 2007 . "Pengaruh Penambahan Serbuk Kayu Terhadap Karakteristik Keramik Cordierite Berpori Sebagai Bahan Filter Gas Buang”. Fisika .7(1), 25-38.

[32] Moniaga,F. 2013 . "Struktur Modal Profitabilitas dan Struktur Biaya Terhadap Nilai Perusahaan Industri Kaca, Keramik dan Porselen Tahun 2007-2011". EMBA : RIset Ekonomi, Manajemen, Bisnis dan Akuntansi. Vol.1

[33] Febrina,L dan Ayuna, A. 2015 . "Studi Penuruna Kadar Besi (Fe) dan Mangan (Mn) Dalam Air Tanah Menggunakan Saringan Keramik" Teknologi. Vol.7.

[34] Agmalini,S., Lingga, N. et al. 2013 . "Peningkatan Kualitas Air Rawa Menggunakan Membran Keramik Berbahan Tanah Liat Alam daan Abu Terbang Batubara”. Teknik Kimia . Vol.19, No (2)

[35] Irawan,B. ( 2010 ) . "Pengaruh Tekanan Kompaksi dan Suhu Sintering Terhadap Kekerasan Keramik Lumpur Lapindo". Prosiding Seminar Nasional dan Internasional. 3(1)

[36] Permadi,B.,Nurmalina,R dan Kirbrando,K. 2016. "Analisis Pengembangan Model Bisnis Canvas Cv Kandura Keramik Bandung”, Aplikasi Manajemen. Vol.14(1)

[37] Indayaningsih,N., et al. 2008. "Studi Awal Peggabungan Antar Komponen Sel Bahan Bakar Berbasis Keramik". Fisika. Vol. 8(1)

[38] Setyowati, E. W. (2012). "Lapindo Sebagai Campuran Untuk Meningkatkan Kekuatan Genteng Keramik”. Rekayasa Sipil., 3(1), 29-35.

[39] Hidayah, L. N. (2011). "Pelaksanaan Kemitraan Pola Dagang Umum di Bidang Kerajinan Keramik di KAbupaten Bantul, Yogyakarta". Hukum. 2(2).

[40] Arifin, F., \& Martomi, E. S. 2009 . "Keramik ( Advancd Ceramics ) Sebagai Material Alternatif di Bidang Kesehatan". AUSTENIT . Vol. 1(1)

[41] Fahad, F., \& Pratapa, S. (2014). "Analisis Komposisi Fasa Komposit Keramik Berbasis $\mathrm{SiO}_{2}-\mathrm{MgO}$ Dengan Penambahan $\mathrm{B}_{2} \mathrm{O}_{3}$ pada Temperatur Sinter $115^{\circ} \mathrm{C} "$. Sains dan Seni. 3(1), B1-B3.

[42] Setiawan, F., Yulianto, A., \& Aji, M. P. (2017). "Analisis Prositas dan Kuat Tekan Campuran Tanah Liat Kaolin dan Kuarsa Sebagai Keramik". MIPA. 40(1), 24-27.

[43] Sanjaya,I.P.A. 2009 . "Pengaruh Jumlah Penggilingaan Tanah Liat Sebagai Bahan Pebuat Genteng Terhadap Karakteristik Genteng Keramik Darmasba". Teknik Sipil.

[44] Normal,I.N. 2015 . "Pengaruh Manajemen Laba Terhadap Rasio Keuangan Produk Industri Keramik Kreatif” Keuangan dan Perbankan. Vol.19

[45] Sandra, K. O., Budi, A. S., \& Sulisto, A. B. (2014). "Pengaruhh Suhu Sintering Terhadap Densitas dan Porositas pada Membran Keramik Berpori Berbasis Arang Balok, Zeolit, Polyvynilalcohol ( PVA ) dan tanah Lempung”. Pertemuan Ilmiah XXVIII HFI Jateng \& DIY, ISSN, 0853-0823.

[46] Walujodjati, A. (2008). Sintesis Hidrotermal dari Serbuk Oksida Keramik. MAJALAH ILMIAH MOMENTUM, 4(2). 
[47] Waskito, M. A. (2014). "Pendekatan Semantik Seni Rupa Sebagai Metoda Pengembangan Desain Dengan Studi Kasus Produk Mug di Industri Keramik". ITENAS REKARUPA, 2(1).

[48] Hartanto,Y dan Gustami,S.P. (2003). "Seni Kerajinan Keramik Bayat Klaten Dadlam Dua Dasawarsa Terakhir Abad XX ( Kontinuitas dan Perubahannya )". SOSIOHUMANIKA. 16(16)

[49] Ariyani,E. 2009 . "Perencanaan Produksi engan Metode De Novo Programming Untuk Memperoleh Keuangan yang Maksimal di PT. Asam Tambang Menggunakan Teknologi Membran Keramik”. Teknik Kimia. Vol.18.

[50] Afrianty, C., Gustin, L., \& Dewi, T. K. (2012). Pengolahan Limbah Air Asam Tambang Menggunakan Teknologi Membran Keramik. Jurnal Teknik Kimia, 18(3).

[51] Widodo, L. (2017). "Potensi Penerapan Konsep Produksi Bersih Pada Industri Keramik di Probolinggo". Teknologi Lingkungan .18(2), 192-199.

[52] Ady, J., \& Maiyanti, A. A. (2014). "Karakteristik Mikroskopik Keramik Batako Terhadap Variasi Penambahan Sekam Tebu". Sains. 14(1), 29-34.

[53] Nawawi, M. 2005 . "Analisis Penerapan Estetika Ragam Hias Pada Kriya Keramik Mahasiswa Jurusan Seni rupa FBS UNIMED”. Seni Rupa. 2(2)

[54] Kuncoro,M dan Supomo,I.A. 2003 . "Analisi Formasi Keterkaitan Pola Kluster dan Orientasi Pasar". Emperika. Vol.16(1)

[55] Suharson, A., \& Asmara, D. A. (2012). "Komposisi Tanah Untuk Teknik Reproduksi Keramik di Sentra Gerabah Pangerjurang Klaten”. Corak. 1(1)

[56] Yusandika, A. D. (2016). Sintesis Keramik Coerdierite Berbasis Silika Sekam Padi Sebagai Material Isolator Listrik. Ilmiah Fisika, 5(2), 161-172.

[57] Isnaini, S. K. (2016). "Bentuk, Teknik dan Fungsi Ragam Hias Keramik Pada Coco Karunia Keramik Probolinggo".. Jurnal Seni Rupa, 4(01).

[58] Sugiyono, E. 2004 . "Pengaruh Prespsi Produk, Harga dan Promosi Terhdap Omset Penjualan Industri Kecil Keramik di Kecamatan Banjarharajo Kabupaten Brebes". EKONOMI. Vol.6

[59] Purnawan, M., Rahardjo, S., \& Lubis, M. S. (2017). Pembuatan dan Karakterisasi Material Cutting Tools Alumina Aditif Titania. Jurnal Keramik dan Gelas Indonesia, 26(2), 96-102.

[60] Sinaga,S dan Asmi,. (2015). "Pengaruh Suhu Pembakaran Terhadap Karakteristik Keramik Silika Daun Bambu Hasil Leachng Asam Sitrat dan Suhu Pembakaran $500^{\circ} \mathrm{C}-700^{\circ} \mathrm{C}$ ". Fisika. 3(1).

[61] Santoso, P. B., Choiri, M., \& Rahman, A. 2013 . "Integrasi Supplier, Produsen dan Pelanggan PAda UKM Keramik Diniyo Dengan Cloud Computing". Rekayasa Mesin . 4(1), 59-66.

[62] Nurhayati,C dan Susanto,T. 2015 . "Pemanfaatan Fly Ash Batubara Sebagai Bahan Membran Keramik Pada Unit Pengolahan Air Gambut". Dinamika Penelitian Industri. Vol.26

[63] Sumantri, A. R., LODRA, I. N., \& ARIEF, M. (2015). “Uji Coba Lumpur Lapindo Untuk Bahan Baku Pembuatan Bodi Keramik Bakaran Tinggi”. Seni Rupa. Vol.3

[64] Kuncoro, H. S., Sulistarihani, N., Manullang, R. J., Purnawan, M., \& Astari, R. R. (2015). Density and Magnetic Properties of Barium Ferrite from 
BaFe12O19 Nanoparticles Prepared by Microemulsion Method. Jurnal Keramik dan Gelas Indonesia, 24(2), 61-71.

[65] Agustina, T. E., Faizal, M., Aprianti, T., Teguh, D., Rif'at, A. M., Putra, I. G., \& Fitrializa, U. (2018). "Pengolahan Limbah Logam Berat Kronium Hexavalen Menggunakan Reagen Fenton an Adsorben Keramik Zeolit". Rekayasa Kimia dan Lingkungan . 13(1).

[66] Mawardani, P. 2014 . "Pengaruh Kemurnian Bahan Baku Aluminium Terhadap Temperatur Sintering dan Karakteristik Keramik Alumina"

[67] Noverliana,N dan Asmi,D. 2017 . "Sintesis Keramik Silika dari Daun Bambu Dengan Teknik Sol-Gel dan Karakterisasi Pada Suhu Kalsinasi $500^{\circ} \mathrm{C}, 600^{\circ} \mathrm{C}$ dan $700^{\circ} \mathrm{C}$ " Fisika. Vol.3

[68] Pojoh, I. H., Sulistyowati, D., Nugraha, A., \& Caesario, D. (2015). Sistem Informasi Arkeologi: Pangkalan Data Berbasis Daring Untuk Perekaman Data Artefak Tembikar Dan Keramik di Kawasan Percandian Muarajambi. AMERTA, 33(2), 77-84.

[69] Dahlan, M. H., Handayani, L., \& Setiono, E. (2011). Pengaruh Penggunaan Membran Keramik Berbasis Zeolit, Silika, dan Karbon Aktif Terhadap Kadar CO Dan CO2 Pada Gas Buang Kendaraan Bermotor. Jurnal Teknik Kimia, 17(8).

[70] Sidabutar, T. E. (2017). Pembuatan dan Karakterisasi Keramik Magnesium Alumina Silika dari Abu Vulkanik Gunung Sinabung. Jurnal Teknik Mesin Mercu Buana, 6(1), 28-35.

[71] Dahlan, M. H., Setiawan, A., \& Rosyada, A. (2014). PEMISAHAN OLI BEKAS DENGAN MENGGUNAKAN KOLOM FILTRASI DAN MEMBRAM KERAMIK BERBAHAN BAKU ZEOLIT DAN LEMPUNG. Jurnal Teknik Kimia, 20(1).

[72] Suhendi, E., Hasanah, L., \& Gustaman, D. S. (2012). Pengaruh penambahan $\mathrm{NiO}$ terhadap karakteristik keramik film tebal $\mathrm{Fe} 2 \mathrm{O} 3$ untuk sensor gas aseton. Jurnal Pendidikan Fisika Indonesia, 8(2).

[73] ]Nugraha, P. R., Widanarto, W., Cahyanto, W. T., \& Kuncoro, H. S. (2015). Pengaruh aditif $\mathrm{BaCO} 3$ pada kristalinitas dan Suseptibilitas Barium Ferit dengan Metoda Metalurgi Serbuk Isotropik. Berkala Fisika, 18(1), 43-50.

[74] Machmud, M. N., \& Jalil, Z. (2015). dampak penggantian Fe3O4 secara parsial dengan abu sekam padi (ASP) terhadap porositas dan kuat tekan keramik komposit clay-Fe3O4. Jurnal Rekayasa Kimia \& Lingkungan, $10(3)$.

[75] Karo-karo, U., \& Komaro, M. (2006). Karakterisasi Bahan Mentah dan Analisa Kegagalan Produk Keramik. TORSI. IV (2).

[76] Taufik, D., Syarif, D. G., \& Karim, S. (2007). Karakteristik keramik termistor NTC dari pasir yarosit yang berstruktur hematit dengan penambahan oksida mangan. In Prosiding Seminar Nasional Sains dan Teknologi Nuklir PTNBR-BATAN Bandung, 17-18 juli 2007.

[77] Natanagara, D. M., \& Juniarti, J. J. (2016). "Pengaruh Pengungkapan Corproate Social Responsiility Terhafap Respon Nilai Perusahaan pada Subsektor Semen, Keramik, Plastil daan Kimia. Journal of Bussines Accounting. 4(1)

[78] Sudiarta, I. W., Diantariani, N. P., \& Suarya, P. (2013). Modifikasi Silika Gel dari Abu Sekam Padi dengan Ligan Difenilkarbazon. Jurnal Kimia. 
[79] Puspitasari, D. (2013). Analisis sifat mekanik dan foto mikroskopis keramik berbahan dasar lempung bersisik (scaly clay) formasi Karangsambung Kebumen (Doctoral dissertation, Universitas Negeri Semarang).

[80] Leman, S. (2017). MODEL ANALISIS 3 DIMENSI PADA SEGMEN BATA KERAMIK BETON.

[81] Shafitri, M., \& Zainul, R. (2019). Vanadium Pentaoksida (V2O5): Termodinamika Molecular dan Interaksi Ion dalam Larutan.

[82] Permana, D. (2017) "MODEL STOKASTIK RANTAI MARKOV EMPAT STATUS PADA PENENTUAN NILAI HIDUP PELANGGAN”, EKSAKTA: Berkala Ilmiah Bidang MIPA, 18(01)

[83] Kurniawati,Y.,Amalita,N dan Syafriandi,S. (2017) "PENERAPAN IMPORTANCE PERFORMANCE ANALYSIS DALAM MENILAI KEPUASAAN STAKEHOLDER TERHADAP KINERJA PKL MAHASISWA D3 STATISTIKA”, EKSAKTA: Berkala Ilmiah Bidang MIPA, 18(01)

[84] Zainul, R., Oktavia, B., Nasra, E., Arianti, V. A., Fatimah, P., Liza, Y. M., \& Setiadi, T. (2018). Studi Pengembangan dan Efektivitas Model Penulisan Karya Ilmiah berbasis Online Data dengan menggunakan Aplikasi Endnote bagi Guru-guru MGMP Kimia Kota Padangpanjang.

[85] Sari, E. S. J., \& Zainul, R. (2019, January 31). Nitrogen Triflorida (NF3) : Termodinamika dan Transpor Elektron NF3. https://doi.org/10.31227/osf.io/3nzrh

[86] Kristy, D. P., \& Zainul, R. (2019, February 3). Analisis Molekular dan Transpor Ion Natrium Silikat. https://doi.org/10.31227/osf.io/8ac4m

[87] Zainul, R. (2016). Studi Literasi Menggunakan Endnote Dan Aplikasi Pembantu (Google Translator, Google Cendikia, Google Sites, Chemoffice 2008, e-learning, dan Snipping Tool).

[88] Zainul, R., Alif, A., Aziz, H., Arief, S., \& Darajat, S. (2015). Modifikasi dan Karakteristik IV Sel Fotovoltaik Cu2o/Cu-Gel Na2so4 Melalui Iluminasi Lampu Neon. Eksakta, 2, 50.

[89] Yanti, C. F., \& Zainul, R. (2018). A Review Ba (OH) 2: Transpor Ionik pada Barium Hidroksida di dalam Air dengan Konsep Termodinamika.

[90] Yulis, R., \& Zainul, R. (2018). DESAIN DAN KARAKTERISASI SEL SURYA SISTEM ELEKTRODA TEMBAGA (I) OKSIDA (Cu2O/Al) MODEL PIPA PADA LARUTAN NATRIUM SULFAT (Na2SO4).

[91] Permana, D. (2017) "MODEL STOKASTIK RANTAI MARKOV EMPAT STATUS PADA PENENTUAN NILAI HIDUP PELANGGAN", EKSAKTA: Berkala Ilmiah Bidang MIPA, 18(01) [92] Delvi, I. P., \& Zainul, R. (2019, February 3). Mercury (II) Nitrate (Hg (NO3)2): Interaksi Molekul dan Adsorpsi Hg dengan Karbon Aktif. https://doi.org/10.31227/osf.io/eqyax

[93] Santoso,B., Setianto, et al. 2018. Mitigation of Land Movement Using Self Potential Method In Ling-Anjung Region, Sumedang Regency.Eksakta. Vol.19

[94] Zainul,R., Oktavia ,B ., Dewata, I dan Efendi, J. (2017). "Studi inamika Molekular dan Kinetika Reaksi Pada Pembelahan Molekul Air Untuk Produksi Gas Hidrogen. 
[95] Alfionita, T., \& Zainul, R. (2019). Calcium Chloride (CaCl2):

Characteristics and Molecular Interaction in Solution.

[96] Syafei, Nendi Suhendi, et al. 2018. " Analysis Cracking Corrosion on Carbon Steel Pipes API 5LX65 in Solution $7700 \mathrm{ml}$ Aquades, $250 \mathrm{ml}$ Acetic Acid and $50 \mathrm{ml}$ Ammonia with Gas $\mathrm{CO} 2$ and $\mathrm{H} 2 \mathrm{~S}$ in Saturation Condition “. Eksakta. Vol.19

[97] Joebaedi,K., Parnikanti, K dan Badrulfalah. (2018). "First Order Space Time Autoregressive Stationary Model on Petroleum Data. EKSAKTA : Berkala Ilmiah Bidang MIPA. Vol.19

[98] Liza, Y. M., Yasin, R. C., Maidani, S. S., \& Zainul, R. (2018). Sol Gel: Principle And Technique (A Review).

[99] Hakimi, A., \& Zainul, R. (2019, January 31). Asam Arsenat (H3AsO4) : Analisis Molekular dan Karakteristik Senyawa. https://doi.org/10.31227/osf.io/e486z

[100] Jumalia, R., \& Zainul, R. (2019, February 3). Natrium Karbonat : Termodinamika dan Transport Ion. https://doi.org/10.31227/osf.io/y2vq9

[101] Hidayati, R., \& Zainul, R. (2019). Studi Termodinamika Transpor Ionik Natrium Klorida Dalam Air dan Campuran Tertentu.

[102] Sari, M., \& Zainul, R. (2018). Kalium Dikromat (K2Cr2O7) Spektroskopi dan Transpor $\mathrm{K} 2 \mathrm{Cr} 2 \mathrm{O} 7$.

[103] Enjelina,W., Mansyurdin dan Meideliza,T. 2018. Analysis of Natural Hybrid Kantung Semar (Nepenthes) in Bukik Taratak West Sumatra with RAPD Technique. Eksakta. Vol.19

[104] Zainul,R., Alif,A., et al. 2015 . : Desain Geometri Reaktor Fotosel Xahaya Ruang “. Riset Kimia. 8(2)

[105] Putri, D. F., Ritonga, H. M., Murdiati, V., \& Zainul, R. (2018). A REVIEW WHAT IS HYDROTHERMAL?.

[106] Prabowo, H. (2018) "PENYELIDIKAN KELAYAKAN KIMIA DAN PENYEBARAN CADANGAN PASIR BESI DAERAH TIKU KABUPATEN AGAM UNTUK BAHAN BAKU SEMEN PADA PT. SEMEN PADANG”. EKSAKTA : Berkala Ilmiah Bidang MIPA.19(1)

[107] Amir, H., Akmam, A., Bavitra, B. and Azhari, M. (2017) "PENENTUAN KEDALAMAN BATUAN DASAR MENGGUNAKAN METODE GEOLISTRIK TAHANAN JENIS DENGAN MEMBANDINGKAN KONFIGURASI DIPOLE-DIPOLE DAN WENNER DI BUKIT APIT PUHUN KECAMATAN GUGUK PANJANG KOTA BUKITTINGGI", EKSAKTA: Berkala Ilmiah Bidang MIPA, 18(01)

[108] Febriani, S. S., Yolanda, T., Arianti, V. A., \& Zainul, R. (2018). A Review Solid Stated: Principles and Methode.

[109] Fatimah, P., Jumalia, R., Novianti, E.R. and Zainul, R. (2018). A REVIEW Teknik Blended: Prinsip dan Dasar-Dasar.

[110] Zainul,R. 2015 . “ Desain dan Modifikasi Kolektor dan Reflektor Cahaya Pada Panel Surya Al/CU $\mathrm{C} \mathrm{Na}_{2} \mathrm{SO}_{4}$ “

[111] Rizki,S.M., Summarin,R. "Pengaruh Ekstrak Daun Sirih Merah (Piper crocatum Ruiz \& Pav) Terhadap Glukosa Dara Mencit (Mus muculus L.) Jantan yang Diinduksi Sukrosa”, EKSAKTA: Berkala Ilmiah Bidang MIPA, 19(1) 
[112] Dinata, A. A., Rosyadi, A. M., Hamid, S., \& Zainul, R. (2018). A Review Chemical Vapor Deposition: Process And Application.

[113] Zainul, R., \& Prima, C. B. (2018, November 11). Desain Geometri Sel PV. https://doi.org/10.31227/osf.io/7n8t4

[114] Zainul,R. 2016 . "Effect of Temperature and Particle Motion Against The Ability of ZnO Semiconductor Photocatalys in Huaman Acid "https://doi.org/10.31227/osf.io/wnygb

[115] Santoso. 2018. “IDENTIFIKASI AKUIFER MENGGUNAKAN GEOLISTRIK RESISTIVITAS DI DAERAH BEBANDEM, KARANG ASEM, BALI", EKSAKTA: Berkala Ilmiah Bidang MIPA, 19(1)

[116] Zainul, R., \& Isara, L. P. (2019, April). “Preparation of Dye Sensitized Solar Cell (DSSC) using anthocyanin color dyes from jengkol shell (Pithecellobium lobatum Benth.) by the gallate acid copigmentation ". In Journal of Physics: Conference Series (Vol. 1185, No. 1, p. 012021). IOP Publishing.

[117] Fadjria,N dan Zainul,R. 2016 . "Isolation and Molecular Identification of Freshwater Microalgae in Maninjau Lake West Sumatera. Der Pharmacial Lettre . (20)

[118] Rahmadhanty, S., \& Zainul, R. (2018). DESIGN OF HUMAT ACID SOLID SOLUTION REACTOR THROUGH PHOTOTRANSFORMATION OF COPPER OXIDE $(\mathrm{CuO})$ SEMICONDUCTOR PLATE.

[119] Utuarima, T. (2017) "SIFAT FISIK DAN KIMIA MARMALADE JERUK KALAMANSI (Citrus microcarpa) : KAJIAN KONSENTRASI PEKTIN DAN SUKROSA Physical and Chemical Properties of Marmalade Citrus of Calamondin (Citrus microcarpa) : Study of Pectin and Sucrose Concentrations", EKSAKTA: Berkala Ilmiah Bidang MIPA, 18(02)

[120] Mawardi,M., et al. 2018 . "Characterization of PCC Cement by Addition of Napa Soil from Subdistrict Sarilamak 50 Kota District as Alternative Additional Material for Semen Padang “. In IOP Conference Series: Materials Science and Engineering (Vol. 335, No. 1, p. 012034). IOP Publishing.

[121] Zainul,R dan Dewata,I. 2015 . "Determination of $p H-B O D-C O D$ and Degradation in Batang Arau Watersheds at Padang City “"

[122] Yasthopi,A. 2015 . "Photoelectosplitting Water for Hydrogen Production Using Illumination of Indoor Lights. Chemichal and Pharmaceutical Research. 7(11).

[123] Zainul,R., Oktavia, B., Dewata, I dan Efendy, I. (2018).“ Thermal and Surface Evaluation on The Process of Forming a Cu2O/CuO Semiconductor Photocatalyst on a Thin Copper Plate ". In IOP Conference Series: Materials Science and Engineering (Vol. 335, No. 1, p. 012039). IOP Publishing.

[124] Zainul, R., Dewata, I., \& Oktavia, B. (2019, April). Fabrication of hexagonal photoreactor indoor lights. In Journal of Physics: Conference Series (Vol. 1185, No. 1, p. 012007). IOP Publishing.

[125] Zainul, R., Effendi, J., \& Mashuri, M. (2019). Phototransformation of Linear Alkylbenzene Sulphonate (LAS) Surfactant Using ZnO-CuO Composite Photocatalyst. KnE Engineering, 1(2), 235-247. 
[126] Zainul,R., Oktavia, B., Dewata, I dan Efendy, I. (2018). Study of Internal Morphology on Preparation of Cu2OThin-Plate using Thermal Oxidation. In Journal of Physics: Conference Series (Vol. 1116, No. 4, p. 042046). IOP Publishing.

[127] Samah, S. (2017) "KARAKTERISASI PLASTIK BIODEGRADABEL DARI LDPE-g-MA DAN PATI TANDAN KOSONG SAWIT”,EKSAKTA

: Berkaa Ilmiah Bidang MIPA, 18(02)

[128] Zainul, R., Aziz.A.N., et al. (2019). Zinc/Aluminium-Quinclorac Layered Nanocomposite Modified Multi-Walled Carbon Nanotube Paste Electrode for Electrochemical Determination of Bisphenol A. Sensors, 19(4), 941.

[129] Handayani, D. (2017) "KARAKTERISTIK CENDAWAN DARK SEPTATE ENDOPHYTE (DSE) PADA AKAR TANAMAN JAGUNG DAN PADI", EKSAKTA: Berkala Ilmiah Bidang MIPA, 18(01)

[130] Cheva, V. K., \& Zainul, R. (2019). PENGEMBANGAN E-MODUL BERBASIS INKUIRI TERBIMBING PADA MATERI SIFAT KEPERIODIKAN UNSUR UNTUK SMA/MA KELAS X. EduKimia, 1(1).

[131] Guci,S.R.F., Zainul,R dan Azhar,M. 2017. “ PENGEMBANGAN MEDIA PEMBELAJARAN BERBASIS TIGA LEVEL REPRESENTASI MENGGUNAKAN PREZI PADA MATERI KESETIMBANGAN KIMIA KELAS XI SMA/MA “.

[132] Sarjani, F., Sri Sumantyo, J. T. and Yohandri, Y. (2017) "PENGOLAHAN CITRA SATELIT ALOS PALSAR MENGGUNAKAN METODE POLARIMETRI UNTUK KLASIFIKASI LAHAN WILAYAH KOTA PADANG", EKSAKTA: Berkala Ilmiah Bidang MIPA, 18(01)

[133] Vauzia,V dan Gusmira,E. “ The Responses of Jabon Seeds Germination (Athocephalus cadamba (Roxb). Miq ) Against The Duration of Combustion and Illumination ". EKSAKTA: Berkala Ilmiah Bidang MIPA, 19(2)

[134] Vauzia,V dan Gusmira,E. " The Responses of Jabon Seeds Germination (Athocephalus cadamba (Roxb). Miq ) Against The Duration of Combustion and Illumination ". EKSAKTA: Berkala Ilmiah Bidang MIPA, 19(2)

[135] Horiza,H.(2018).' The Influence of the Use Of Activated Carbon Fibres Of The Cane Against The Drop In Salinity In the well Dig In RT 003 RW 006 Village Cape Town Unggat Tanjungpinang Year 2017”, EKSAKTA: Berkala Ilmiah Bidang MIPA, 19(1)

[136] Aumi, V., \& Zainul, R. (2018). Pengembangan Bentuk Lembar Kerja Siswa (LKS) untuk Aktivitas Kelas dan Laboratorium Berbasis Inkuiri Terbimbing pada Pokok Bahasan Laju Reaksi.

[137] Suryelita, S., Etika, S. B. and Kurnia, N. S. (2017) "ISOLASI DAN KARAKTERISASI SENYAWA STEROID DARI DAUN CEMARA NATAL (Cupressus funebris End1.)", EKSAKTA: Berkala Ilmiah Bidang MIPA, 18(01)

[138] Putri, G. E., Arief, S., Jamarun, N., Gusti, F. R., \& Zainul, R. (2018). Microstuctural Analysis and Optical Properties of Nanocrystalline Cerium Oxides Synthesized by Precipitation Method.

[139] Ramli,R.,Jonuarti,R an Hartono,A. (2017) “ANALISIS STRUKTUR NANO DARI LAPISAN TIPIS COBALT FERRITE YANG DIPREPARASI DENGAN METODE SPUTTERING", EKSAKTA: Berkala Ilmiah Bidang MIPA, 18(01) 
[140] Syafei,N.(2018).’RISET MATERIAL ANALISIS FENOMENA KOROSI PELAT PIPA BAJA KARBON API 5L-X65 DALAM LARUTAN 7900 ML AIR LAUT DAN 100 ML AMONIAK PADA KONDISI GAS CO2 DAN H2S JENUH PADA SUHU RUANG.”, EKSAKTA: Berkala Ilmiah Bidang MIPA, 19(1)

[141] Horiza H, Azhar.M dan Efendi,J. 2017 . “ Ekstraksi dan Karakteeristik Inulin dari Umbi Dahlia (Dahlia sp.L) Segat dan Disimpan “. EKSAKTA: Berkala Ilmiah Bidang MIPA.

[142] Iskandar,I Horiza dan Fauzi, N. (2017). "Efektivitas Bubuk Biji Pepaya (Carica Papaya L) Sevagai Larvasida Alami Terhadap Kematian Larva Aedes Aegypty Tahun 2015".EKSAKTA: Berkala Ilmiah Bidang MIPA, 18(01)

[143] Sanjaya, H. (2018) "DEGRADASI METIL VIOLET MENGGUNAKAN KATALIS ZnO-TiO2 SECARA FOTOSONOLISIS”, EKSAKTA: Berkala Ilmiah Bidang MIPA, 19(1)

[144] Parbuntari,H., Prestica, Y., et al. 2018. "Preliminary Phytochemichal Screening ( Qualitative Analysis ) of Cacao Leaves ( Theobroma Cacao L.). EKSAKTA : Brkala Ilmiah Bidang MIPA. Vol.19

[145] Badrulfalah., Irianingsih,I dan Khafsah. 2018. " Some Operation on Mixed Mototone Operator in Banach Spaces “. Eksakta. Vol.19

[146] Syafei, Nendi Suhendi, et al. 2018. " Analysis Cracking Corrosion on Carbon Steel Pipes API 5LX65 in Solution $7700 \mathrm{ml}$ Aquades, $250 \mathrm{ml}$ Acetic Acid and $50 \mathrm{ml}$ Ammonia with Gas CO2 and H2S in Saturation Condition “. Eksakta. Vol.19

[147] Multahadah, C. (2018) “ANALISIS KLASIFIKASI AKREDITASI SMA/MA BERDASARKAN FAKTOR-FAKTOR YANG MEMPENGARUHI SE PROVINSI JAMBI DENGAN RLTOG", EKSAKTA: Berkala Ilmiah Bidang MIPA, 19(1)

[148] Advinda, L.2018.“ PERTUMBUHAN STEK HORIZONTAL BATANG TANAMAN JARAK (Jatropha curcas L.) YANG DIINTRODUKSI DENGAN PSEUDOMONAD FLUORESEN", EKSAKTA: Berkala Ilmiah Bidang MIPA, 19(1)

[149] Ruswandi, R. (2018) "Determination of Fructose Content resulted by Inulin Hydrolysis with DNS as Oxidizer".EKSAKTA : Berkala Ilmiah Bidang MIPA.19(1)

[150] Yanuar,F., Tillah, M dan Devianto,D. 2018. “ Modeeling of Human evelopment Inex Using Ridge Regression Method “. Eksakta. Vol.19

[151] Chatri,M.Mansyurin, et al.. (2017) "PERBANDINGAN KOMPONEN MINYAK ATSIRI ANTARA DAUN MUDA DAN DAUN DEWASA PADA HYPTIS SUAVEOLENS (L.)POIT”, EKSAKTA: Berkala Ilmiah Bidang MIPA, 18(02)

[152] Dinata,M dan Soehardi,F. (2018). " Factor Analysis of Physical Chemistry Waters that Affect Damage Safety Cliff on the Outskirts of River Siak ". EKSAKTA:Berkala Ilmiah Bdiang MIPA.19(1)

[153] Iryani,I., et al . (2018). “UJI AKTIVITAS ANTI DIABETES MELLITUS SENYAWA METABOLIT SEKUNDER FRAKSI AIR DARI BERAS 
KETAN HITAM ( Oryza satival. Var glutinosa) PADA MENCIT PUTIH", EKSAKTA: Berkala Ilmiah Bidang MIPA, 18(01)

[154] Prabowo, H. (2018). "Penyelidikan Kelayakan Kimia dan Penyebaran Cadangan Pasir Besi Daerah Tiku Kabupaten Agam Untuk Bahan Baku Semen pada PT. Semen Padang“" EKSAKTA: Berkala Ilmiah Bidang MIPA, 19(1)

[155] Rizki,S.M., Summarin,R. "Pengaruh Ekstrak Daun Sirih Merah (Piper crocatum Ruiz \& Pav) Terhadap Glukosa Dara Mencit (Mus muculus L.) Jantan yang Diinduksi Sukrosa", EKSAKTA: Berkala Ilmiah Bidang MIPA, 19(1)

[156] Joebaedi, K. (2018) "MODEL STAR(1;1) PADA DATA PRODUKTIVITAS TEH”. EKSAKTA : Berkala Ilmiah Bidang MIPA. 19(1)

[157] Harahap, Fatma Suryani., Lubis, LailaTussifah.(2018). "Analysis of Heavy Metals Distribution in the River Town of Hamasaki's Rod Padangsidimpuan". EKSAKTA: Berkala Ilmiah Bidang MIPA. 19(1)

[158] Welyyanti, D. (2018) "BEBERAPA SYARAT CUKUP UNTUK BILANGAN KROMATIK LOKASI HINGGA PADA GRAF TAK TERHUBUNG", EKSAKTA: Berkala Ilmiah Bidang MIPA, 19(1)

[159] Sofiyanita dan Octaria,Zona. (2018). "Fenthion Compound Degradation in the Pesticide Bayleton $500 \mathrm{ec}$ in Sonolysis, Ozonolysis and Sonozolysis with Addition of $\mathrm{TiO}_{2}$-anatase ". EKSAKTA : Berkala Ilmiah Bidang MIPA. 19(1) 